\title{
Soil Organic Carbon, Phosphorus and Potassium in Soils under Poplar Based Agro-Forestry in Punjab
}

\author{
Navjot Kaur Dhillon ${ }^{1 *}$, Pritpal Singh ${ }^{2}$ and Harinder Singh ${ }^{3}$ \\ ${ }^{1}$ Directorate of Extension Education, Punjab Agricultural University, Ludhiana, India \\ ${ }^{2}$ Krishi Vigyan Kendra, Mansa, PAU, Punjab, India \\ ${ }^{3}$ Farm Advisory Service Centre, Faridkot, PAU, Punjab, India \\ *Corresponding author
}

Keywords

Bulk density, Poplar based agro-forestry, C sequestration, SOC stock, available-P, Available-K

Article Info

Accepted:

11 June 2020

Available Online:

10 July 2020
Soil samples $(0-60 \mathrm{~cm})$ were collected from poplar based agro-forestry system varying in age from 2-20 years to study changes in total soil organic $\mathrm{C}$ (SOC), available phosphorus (P) and potassium (K). Soil plough layer (0$15 \mathrm{~cm}$ ) had significantly higher SOC concentration by 34, 61 and $83 \%$, compared with 15-30, 30-45 and 45-60 cm soil depths, respectively. Soil organic $\mathrm{C}$ decreased significantly with increasing soil depth, regardless of the age of poplar plantation period. The concentration of available-P and $\mathrm{K}$ was significantly higher in the surface soil, and decreased with increasing soil depth. Available-P increased significantly $(p<0.05)$ by $16.3-17.7 \%$ and available-K by $36.5-52.4 \%$ in soil plough layer $(0-15 \mathrm{~cm})$ under agroforestry for 20-yrs, compared with soils under agro-forestry for 2-yrs. Soils under 20-yrs old agro-forestry system had $39.8 \%$ and $50.6 \%$ higher SOC in 0-7.5 $\mathrm{cm}$ and 7.5-15 cm soil depth, compared with soils under 2-yrs old plantation. These results revealed $\mathrm{C}$ and nutrients ( $\mathrm{P}$ and $\mathrm{K}$ ) sequestration potential of poplar based agro-forestry system.

\section{Introduction}

Soil is an important sinks of $\mathrm{C}$ as soil organic carbon (SOC), and plays a major role in its cycling in terrestrial ecosystems. As an important component of the $\mathrm{C}$ system, SOC acts as a key indicator for assessing soil quality and plays an important role in increasing crop productivity (Gregorich et al., 1994). On a global scale, soils contains 1500 $\mathrm{Pg}\left(1 \mathrm{Pg}=10^{15} \mathrm{~g}\right)$ of organic $\mathrm{C}$ in the first meter of soil profile. The SOC pool comprise $60 \%$ of this total, $\sim 170 \mathrm{Pg}$ of which are stored in 1.7 billion hectares of agricultural croplands worldwide (Paustian et al., 2000; Lal, 2008). Upper $30 \mathrm{~cm}$ soil layer stores 
almost half of SOC that represents upto 3times of the $\mathrm{C}$ stored in vegetation (Powlson et al., 2011), and therefore is considered most vulnerable to be lost as carbon dioxide $\left(\mathrm{CO}_{2}\right)$. Because of the historic losses of organic $\mathrm{C}$ from croplands, most of cultivated soils are exhausted of SOC and are far away from saturation (Vaccari et al., 2011). Depletion of the SOC pool in cultivated lands has been attributed to lower $\mathrm{C}$ input, and higher $\mathrm{C}$ outputs through oxidation, leaching of dissolved organic C, and soil erosion (Lal 2004, Ghosh et al., 2012). Land-use change in different agro-ecosystems largely determined the potential for SOC storage and ultimately $\mathrm{C}$ sequestration in soil (Bronick and Lal, 2005) due to remarkable alterations in organic $\mathrm{C}$ inputs and dynamics. Agro-forestry is believed to increase the soil organic matter (SOM) through the addition of above and below-ground biomass to soil.

Poplar (Populus deltoids) plantation under agro-forestry annually add 2.9-3.3 $\mathrm{Mg}$ biomass ha ${ }^{-1}$ and could supply $2.3 \mathrm{t} \mathrm{C} \mathrm{ha}^{-1} \mathrm{yr}^{-1}$ as roots and leaves (Chauhan et al., 2011; Singh and Sharma, 2007). Agro-forestry affects nutrient status of soils via addition of leaf litter and also by plant uptake, and is considered an important option for C sequestration (Albrecht and Kandji, 2003). Nutrient availability in soils is influenced by the addition of organics (Gill and Meelu, 1983; Toor and Bahl, 1997; Sui and Thompson, 2000; Singh et al., 2010).

After decomposition, poplar leaf and root biomass adds organic matter to the soil and may alter nutrient availability in soils. The information on the effect of cumulative addition of leaf and root biomass of poplar on SOC and available nutrients is known to lesser extent. Therefore, a study was conducted to investigate the effect of age of poplar based agro-forestry on profile distribution of TOC in sub-tropical soils.

\section{Materials and Methods}

Soil samples (0-60 $\mathrm{cm}$ depth) were collected from different sites under 2-20 years poplar based agro-forestry in sub-tropical area of Ropar district (Punjab, India) during ( ). Soil bulk density $\left(\mathrm{D}_{b}\right)$ at surface and sub-surface soil layers was determined by core method using metallic cores. Soil cores collected from each sampling were oven dried at $105^{\circ} \mathrm{C}$ for $24 \mathrm{~h}$, and dry soil weight was recorded (Blake and Hartge 1986). The $\mathrm{D}_{b}\left(\mathrm{Mg} \mathrm{m}^{-3}\right)$ was calculated as: $\mathrm{D} b=\mathrm{Ws} / \mathrm{Vt}$, Where, ' $W s$ ' is weight of soil $(\mathrm{Mg})$ and $V t$ is the volume of soil sample $\left(\mathrm{m}^{3}\right)$. Soil samples were analyzed for soil $\mathrm{pH}$ (1:2 soil: water suspension) with a glass electrode (Elico, India), electrical conductivity (E.C., 1:2 soil: water supernatant) using a conductivity meter (Elico, India). Available $\mathrm{P}$ in soil samples was determined by extracting with $0.5 \mathrm{M}$ sodium bicarbonate $(\mathrm{pH}$ 8.5; 1:20 soil: extractant) (Olsen et al., 1954) and measuring $\mathrm{P}$ concentration in the extract colorimeterically (Murphy and Rilay, 1962). Available K in soil samples was extracted with $1 \mathrm{~N}$ ammonium acetate ( $\mathrm{pH}$ 7.0) (Mervin and Peech, 1950) followed by flame photometric determination. Total organic carbon (TOC) in soil was determined by using $1 \mathrm{~N} \quad \mathrm{~K}_{2} \mathrm{Cr}_{2} \mathrm{O}_{7}$ solution followed by heating at $150{ }^{\circ} \mathrm{C}$ for 1 hour (Snyder and Trofymow, 1984). Total organic $\mathrm{C}$ stock (as $\mathrm{Mg} \mathrm{C} \mathrm{ha}{ }^{-1}$ ) in the $0-15 \mathrm{~cm}$ soil plough layer was computed by multiplying the respective TOC concentration (\%) with measured soil bulk density $\left(\mathrm{Mg} \mathrm{m}^{-3}\right)$ and depth $(\mathrm{m})$ of sampling using the following formula:

TOC stock $\left(\mathrm{MgCha}^{-1}\right)=\operatorname{TOC}(\%) \times$ Soil depth $(\mathrm{m}) \times$ Bulk density $\left(\mathrm{Mg} \mathrm{m}^{-3}\right) \times 100$

\section{Statistical analysis}

Statistical analysis of soil samples collected under different agro-forestry systems varying in age was performed by one way analysis of 
variance (ANOVA) with SPSS for Windows 16.0 (SPSS Inc., Chicago, U.S.A.). Mean separation for different land-uses was performed using the Duncan's multiple range test (DMRT). Differences in land-use mean at $p<0.05$ were considered statistically significant.

\section{Results and Discussion}

Soils under agro-forestry were non-saline (EC $0.25-0.43 \mathrm{dS} \mathrm{m}^{-1}$ ) and near neutral to slightly alkaline in reaction ( $\mathrm{pH} 7.87-8.02)$ (Table 1). Soils were classified as Typic Udorthents and Udic Haplustepts (USDA, 1999). Regardless of the age of poplar plantation, available $\mathrm{P}$ was significantly higher in the surface (0-7.5 $\mathrm{cm}$ ) soil, and decreased significantly with increasing soil depth (Table 1, Figure 1b). Soils under 20-yr agro-forestry had significantly higher available-P, compared with soils under $<15 \mathrm{yr}$ poplar plantation. Available $\mathrm{K}$ concentration (52-131 $\mathrm{mg} \mathrm{kg}^{-1}$ ) was significantly higher in the surface than the sub-surface soil (Figure 1c). A significant increase in available $K$ concentration with increasing age of poplar plantation was observed in the surface soil. In the subsurface soil, available-K increased significantly after $15-\mathrm{yr}$ of poplar plantation. Soils under <10-yr agro-forestry did not exhibit a significant change in available $\mathrm{K}$ concentration (Table 2). Higher concentration of available $\mathrm{P}$ and $\mathrm{K}$ in the surface $(0-7.5 \mathrm{~cm})$ soil depth could be ascribed to application of fertilizer-P and $\mathrm{K}$ in the surface soil. The deciduous poplar plants shed their leaves before entering dormant stage during winter season (mid-December to end-January) adds large amount biomass and organic matter to the soil (Chauhan et al., 2011; Singh and Sharma, 2007). Increased $P$ availability in soils with increasing age of poplar plantation could be ascribed to $\mathrm{P}$ mineralization from added organic matter as leaf litter (Gill and Meelu, 1983; Hundal et al., 1988; Sui and Thompson, 2000). The production of organic acids (Wang et al., 1967), organic anions such as citrate, oxalate and tartrate (Ibia and Udo, 1993) during the process of organic matter decomposition enhance solubility of native and freshly applied P (Toor and Bahl, 1997; Singh et al., 2010). Organic acids tends to compete with phosphate ions for $\mathrm{P}$ sorption sites on soil colloidal complex, decreases its fixation and causing a large flush of available $\mathrm{P}$ in the soil solution (Singh et al., 2010).

Table.1 Important properties of soil samples collected from fields under poplar based agro-forestry

\begin{tabular}{|c|c|c|c|c|c|}
\hline \multirow{2}{*}{ Soil property } & \multicolumn{5}{|c|}{ Depth (cm) } \\
\hline & $0-7.5$ & $7.5-15$ & $15-30$ & $30-45$ & $45-60$ \\
\hline $\mathbf{p H}_{1: 2}$ & $\begin{array}{c}7.94^{\mathrm{a}} \\
(7.88-8.02)^{\mathbb{I}}\end{array}$ & $\begin{array}{c}7.89^{\mathrm{a}} \\
(7.87-8.02)\end{array}$ & $\begin{array}{c}7.88^{\mathrm{a}} \\
(7.86-7.92)\end{array}$ & $\begin{array}{c}7.87^{\mathrm{a}} \\
(7.84-7.93)\end{array}$ & $\begin{array}{c}7.86^{\mathrm{a}} \\
(7.84-7.88)\end{array}$ \\
\hline E.C. $\cdot 1: 2$ & $\begin{array}{c}0.30^{\mathrm{a}} \\
(0.25-0.35)\end{array}$ & $\begin{array}{c}0.32^{\mathrm{b}} \\
(0.26-0.43)\end{array}$ & $\begin{array}{c}0.30^{\mathrm{a}} \\
(0.25-0.35)\end{array}$ & $\begin{array}{c}0.31^{\mathrm{a}} \\
(0.25-0.36)\end{array}$ & $\begin{array}{c}0.31^{\mathrm{a}} \\
(0.26-0.36)\end{array}$ \\
\hline Available-P $\left(\mathrm{mg} \mathrm{kg}^{-1}\right)$ & $\begin{array}{c}13.9^{\mathrm{e}} \\
(12.9-15.0)\end{array}$ & $\begin{array}{c}12.1^{\mathrm{d}} \\
(11.0-13.3)\end{array}$ & $\begin{array}{c}9.7^{\mathrm{c}} \\
(8.3-10.5)\end{array}$ & $\begin{array}{c}8.2^{\mathrm{b}} \\
(7.5-8.5)\end{array}$ & $\begin{array}{c}6.7^{\mathrm{a}} \\
(5.6-7.9)\end{array}$ \\
\hline Available-K $\left(\mathrm{mg} \mathrm{kg}^{-1}\right)$ & $\begin{array}{c}118^{\mathrm{e}} \\
(96-131)\end{array}$ & $\begin{array}{c}111^{\mathrm{d}} \\
(83-125)\end{array}$ & $\begin{array}{c}86^{\mathrm{c}} \\
(69-103)\end{array}$ & $\begin{array}{c}72^{\mathrm{b}} \\
(65-88)\end{array}$ & $\begin{array}{c}60^{\mathrm{a}} \\
(52-70)\end{array}$ \\
\hline Bulk density $\left(\mathrm{Mg} \mathrm{m}^{-3}\right)$ & $\begin{array}{c}1.42^{\mathrm{a}} \\
(1.38-1.46)\end{array}$ & $\begin{array}{c}1.44^{\mathrm{b}} \\
(1.40-1.47)\end{array}$ & $\begin{array}{c}1.44^{\mathrm{b}} \\
(1.41-1.49)\end{array}$ & $\begin{array}{c}1.46^{\mathrm{c}} \\
(1.43-1.48)\end{array}$ & $\begin{array}{c}1.47^{c} \\
(1.44-1.50)\end{array}$ \\
\hline
\end{tabular}

Values in the parentheses indicate range (minimum-maximum)

Mean values for different soil depths followed by different letter are significant $(p<0.05)$ by Duncan's multiple range test (DMRT). Bars indicate standard error from mean. 
Table.2 Available-P and available K concentration in surface $(0-7.5 \mathrm{~cm})$ and sub-surface $(7.5-15 \mathrm{~cm})$ soils under agro-forestry

\begin{tabular}{|l|c|c|c|c|}
\hline \multirow{2}{*}{$\begin{array}{l}\text { Age of } \\
\text { plantation }\end{array}$} & \multicolumn{2}{|c|}{ Available-P $\mathbf{( \mathbf { m g ~ k } ^ { - \mathbf { 1 } } )}$} & \multicolumn{2}{|c|}{ Available-K $\left.\mathbf{( m g ~ k g ~}^{-\mathbf{1}}\right)$} \\
\hline & $0-7.5 \mathrm{~cm}$ & $7.5-15 \mathrm{~cm}$ & $0-7.5 \mathrm{~cm}$ & $7.5-15 \mathrm{~cm}$ \\
\hline $\mathbf{2}-\mathbf{y r}$ & $12.9^{\mathrm{a}}$ & $11.3^{\mathrm{a}}$ & $96^{\mathrm{a}}$ & $82^{\mathrm{a}}$ \\
\hline $\mathbf{5}-\mathbf{y r}$ & $13.3^{\mathrm{a}}$ & $11.5^{\mathrm{a}}$ & $119^{\mathrm{b}}$ & $115^{\mathrm{b}}$ \\
\hline $\mathbf{1 0}-\mathbf{y r}$ & $14.0^{\mathrm{b}}$ & $11.0^{\mathrm{a}}$ & $121^{\mathrm{b}}$ & $115^{\mathrm{b}}$ \\
\hline $\mathbf{1 5}-\mathbf{y r}$ & $14.6^{\mathrm{c}}$ & $13.2^{\mathrm{b}}$ & $125^{\mathrm{c}}$ & $118^{\mathrm{b}}$ \\
\hline $\mathbf{2 0}-\mathbf{y r}$ & $15.0^{\mathrm{c}}$ & $13.3^{\mathrm{b}}$ & $131^{\mathrm{d}}$ & $125^{\mathrm{c}}$ \\
\hline
\end{tabular}

Mean values for different soil depths followed by different letter are significant $(p<0.05)$ by Duncan's multiple range test (DMRT). Bars indicate standard error from mean.

Figure.1 Profile distribution of total soil organic carbon (SOC) (A), available-P (B) and available-K (C) in soils under different age of agro-forestry in Ropar district of Punjab (India). Mean values for a soil depth followed by different letter are significant $(p<0.05)$ by Duncan's multiple range test (DMRT)
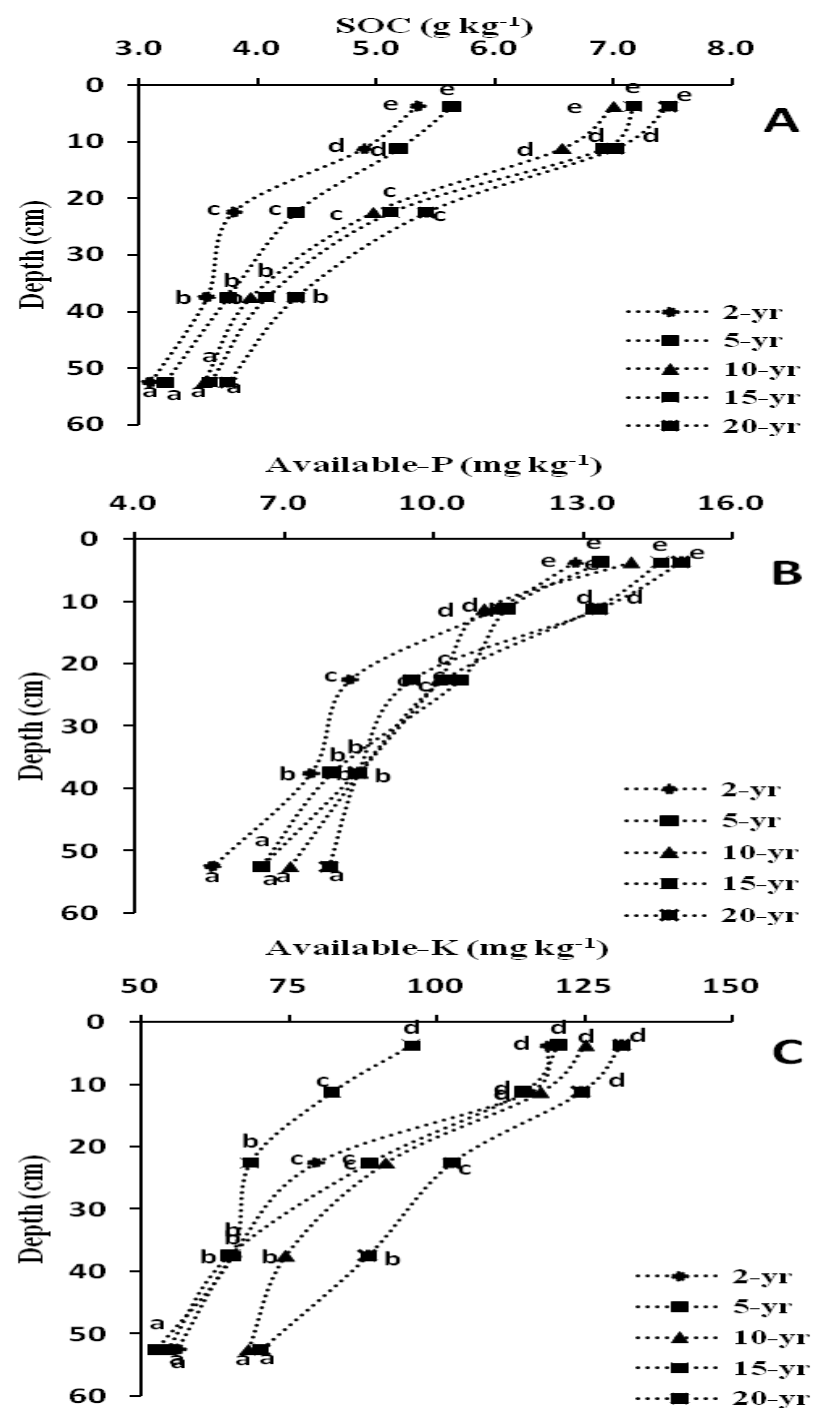
Figure.2 Total soil organic carbon (SOC) stocks in surface $(0-7.5 \mathrm{~cm})$ and sub-surface $(7.5-15$ $\mathrm{cm})$ soil depths under different age of agro-forestry. Mean values followed by different letter are significant $(p<0.05)$ by Duncan's multiple range test (DMRT). Bars indicate standard error from mean

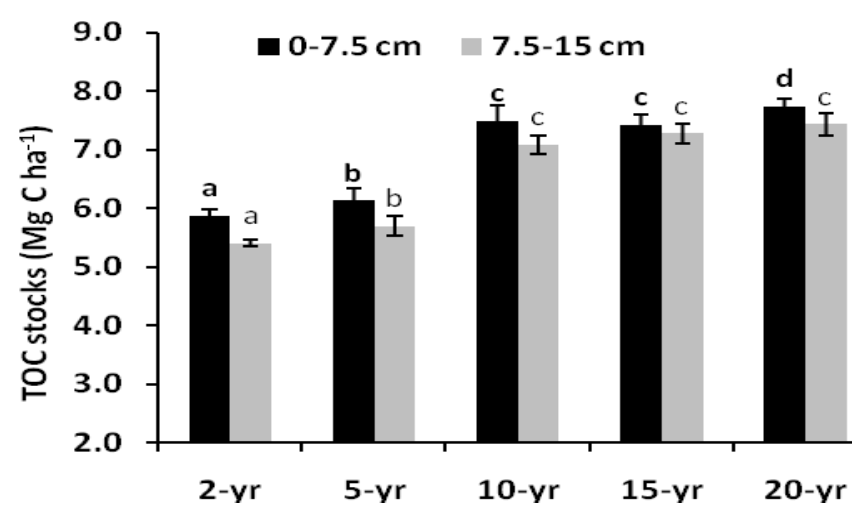

Figure.3 Relationship between soil bulk density $\left(\mathrm{D}_{b}\right)$ and total soil organic carbon (SOC) in soils under poplar based agro-forestry in Ropar district of Punjab. Bars indicate standard error from mean

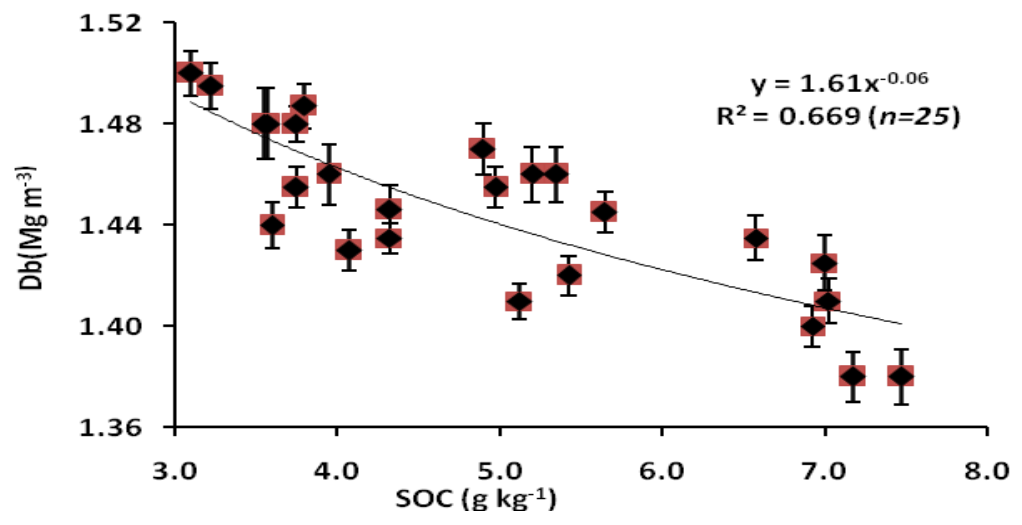

Figure.4 Diameter at breast height (DBH) and diameter at scum height (DSH) of poplar (Populus deltoids) plants in relation to age of plantation. Mean values followed by different letter are significant $(p<0.05)$ by Duncan's multiple range test (DMRT). Bars indicate standard error from mean

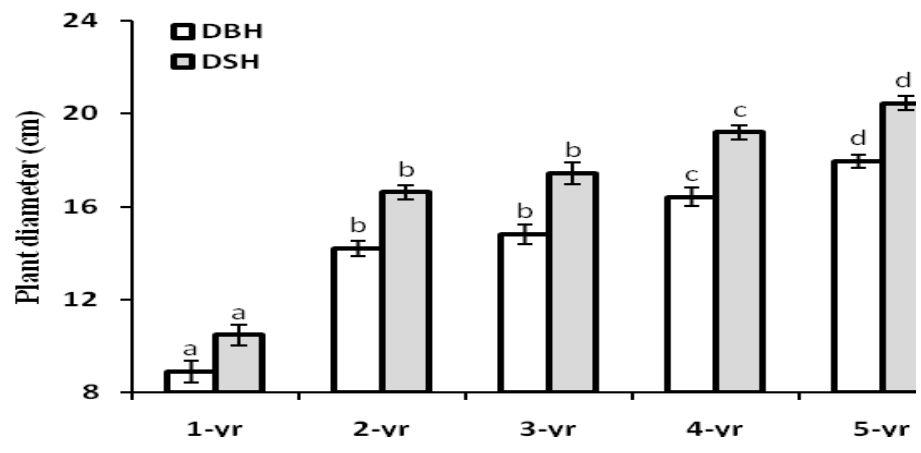


Total organic $\mathrm{C}$ concentration in the surface soils was significantly higher than the subsurface soil, regardless of the age of agroforestry system (Figure 1a). In general, TOC decreased with increasing soil depth. In a plough layer $(0-15 \mathrm{~cm})$, SOC pool was significantly $(p<0.05)$ higher by $\sim 34,61$ and $83 \%$ than in $15-30,30-45$ and $45-60 \mathrm{~cm}$ soil depths, respectively. Surface $(0-7.5 \mathrm{~cm})$ soil depth had $\sim 0.4 \mathrm{~g} \mathrm{~kg}^{-1}$ ( 7\%) higher SOC concentration, compared with $7.5-15 \mathrm{~cm}$ soil depth. Higher TOC concentration in the surface $(0-7.5 \mathrm{~cm})$ than sub-surface soil layers, regardless of the age of agro-forestry could be due to higher $\mathrm{C}$ being contributed by plant roots in $0-7.5 \mathrm{~cm}$ soil depth, owing to higher root density and incorporation of leaf litter. A linear significant relationship between $\mathrm{C}$ input and SOC concentration across different treatments has also been well documented (Larson et al., 1972; Paustian et al., 1997).

The TOC was higher in soils under 20-yr agro-forestry, compared the soils under relatively younger agro-forestry system. Total organic C stocks in surface soil under 20-yr agro-forestry system were significantly higher, although TOC stocks in soils under 10 -and 15-yr of agro-forestry did not differ significantly (Figure 2). In the sub-surface soil, TOC stocks were significantly higher under agro-forestry older than 10-yr, while TOC stocks did not differ significantly under 10-, 15-and 20-yr agro-forestry system.

Soil bulk density $\left(D_{b}\right)$ of the surface soil ranged from 1.38 to $1.46 \mathrm{Mg} \mathrm{m}^{-3}$ and 1.40 to $1.47 \mathrm{Mg} \mathrm{m}^{-3}$ in the sub-surface soil. Bulk density was significantly higher for $45-60 \mathrm{~cm}$ soil depth, compared with top soil $(0-45 \mathrm{~cm})$. Soils under 20-yr agro-forestry had lower $D_{b}$, compared with other sites (Table 1). Soil $\mathrm{D}_{b}$ decreased as a function of increasing SOC content (Figure 3). Decrease in $\mathrm{D}_{b}$ of soils under 20-yr agro-forestry system was due to addition of organic matter to soil as leaf litter and root biomass input. Halvorson et al., (1999) ascribed this decrease in soil $\mathrm{D}_{b}$ in response to added organic matter to the higher $\mathrm{C}$ concentration and increased root biomass which resulted in better soil aeration and aggregation. The fibrous nature of added organic matter acts as a fairly rigid framework preventing closer packing of soil separates, and thereby decreases soil $\mathrm{D}_{b}$ (Adams, 1973).

In conclusion, long-term adoption of agroforestry system increased TOC, available-P and available- $K$ concentration in the surface soil increased with increase in age of agroforestry system, and decrease with increasing soil depth. Agro-forestry system could enhance $\mathrm{C}$ sequestration and improve soil physical condition.

\section{References}

Adams WA 1973. The effect of organic matter on the bulk and true densities of some uncultivated podzolic soils. J. Soil Sci. 24: 10-17.

Albrecht A and Kandji ST 2003. Carbon sequestration in tropical agroforestry systems. Agric. Ecosys. \& Environ. 99: 15-27.

Blake GR and Hartge KH 1986. Bulk density. In: Klute, A. (Ed.), Methods of soil analysis. Part I: Physical and Mineralogical Methods, Agronomy Monograph No. 9. ASA-SSSA, Madison, pp. 363-375.

Bronick CJ and Lal R 2005. Soil structure and management: a review. Geoderma 124: 3-22.

Chauhan SK, Gupta N, Walia R, Yadav S, Chauhan R and Mangat PS 2011. Biomass and carbon sequestration potential of poplar-wheat intercropping system in irrigated agroecosystem in India. J. Agric. Sci. Technol. 1:575-586. Ghosh S, Wilson B, Ghoshal S, Senapati N 
and Mandal B 2012. Organic amendments influence soil quality and carbon sequestration in the IndoGangetic Plains of India. Agri. Ecosyst.\& Environ. 156:134-41.

Gill HS and Meelu OP 1983. Studies on the utilization of phosphorus and causes for its differential response in rice-wheat rotation. Plant\& Soil 74: 211-222.

Gregorich EG, Carter MR, Angers DA, Monreal CM and Ellert BH 1994. Towards a minimum data set to assess soil organic matter quality in agricultural soils. Can. J. Soil Sci. 74: 367-385.

Halvorson AD, Reule CA and Follett RF 1999. Nitrogen fertilization effects on soil carbon and nitrogen in a dryland cropping system. Soil Sci. Soc. Am. J. 63:912-917.

Hundal HS, Biswas CR and Vig AC 1988. P sorption characteristics of flooded soils amended with green manure. Tropical Agric.(Trinidad) 65:185-186.

Ibia TO and Udo EJC 1993. Phosphorus forms and fixation capacity of representative soils of Akwa Ibom state of Nigeria. Geoderma 58: 95-106.

Lal R 2004. Soil carbon sequestration impacts on global climate change and food security. Sci. 304:1623-1627.

Lal R 2008. Soil carbon stocks under present and future climate with specific reference to European eco-regions. Nutri. Cycl. Agroecosyst. 81:113-127.

Larson WE, Clapp CE, Pierre WH and Morachan YB 1972. Effects of increasing amounts of organic residues on continuous maize: II. Organic carbon, nitrogen, phosphorus, and sulfur. Agron. J. 64: 204-208.

Mervin HD and Peech M 1950. Exchangeability of soils potassium in the sand, silt and clay fractions as influenced by the nature of the complementary exchangeable cations.
Soil Sci. Soc. Am. Proc. 15:125-128.

Murphy J and Rilay JP 1962. A modified single solution method for the determination of phosphate in natural water. Anal. Chem. Acta. 27: 6-31.

Olsen SR, Cole CV, Watanabe FS and Dean AL 1954 Estimation of available phosphorus in soils by extraction with sodium bicarbonate. United States Dept Agric Circ 939, pp. 1-19.

Paustian K, Collins HP and Paul EA 1997. Management controls on soil carbon. In: Paul, E.A. (Ed.), Soil Organic Matter in Temperate Agroecosystems. CRC Press, Boca Raton, FL, pp. 15-49.

Paustian K, Six J, Elliott ET and Hunt HW 2000. Management options for reducing $\mathrm{CO}_{2}$ emissions from agricultural soils. Biogeochem. 48: 147-163.

Powlson DS, Gregory PJ, Whalley WR, Quinton JN, Hopkins DW, Whitmore AP, Hirsch PR and Goulding KWT 2011. Soil management in relation to sustainable agriculture and ecosystem services. Food Policy 36: S72-S87.

Singh B and Sharma KN 2007. Tree growth and nutrient status of soil in a poplar (Populus deltoides Bartr.)-based agroforestry system in Punjab, India. Agroforestry Syst 70:125-134.

Singh P, Singh H and Bahl GS 2010. Phosphorus supplying capacity of pressmud amended recent floodplain soils under different moisture regimes. J. Indian Soc. Soil Sci. 58:168-181.

Snyder JD and Trofymow JA 1984. A rapid accurate wet oxidation diffusion procedure for determining organic and inorganic carbon in pot and soil samples. Commun. Soil Sci. \& Plant Anal. 15:587-597.

Sui Y and Thompson ML 2000. Phosphorus sorption, desorption and buffering capacity in a biosolidamended Mollisols. Soil Sci. Soc. Am. J. 64: 164169. 
Toor GS and Bahl GS 1997. Effect of solitary and integrated use of poultry manure and fertilizer phosphorus on the dynamics of $\mathrm{P}$ availability in different soils. Bioresources Technol. 62: 25-28.

USDA 1999. Soil taxonomy: a basic system of soil classification for making and interpreting soil survey. Agriculture Handbook No. 436. United States Department of Agriculture, Natural
Resource Conservation Service, Washington, D.C. (869 pp.).

Vaccari FP, Baronti S, Lugato E, Genesio L, Castaldi S, Fornasier F and Miglietta, F 2011. Biochar as a strategy to sequester carbon and increase yield in durum wheat. European J. Agron. 58: 478-86. Wang TSC, Cheng S and Tung H 1967. Dynamics of soil organic acids. Soil Sci.104: 138- 144.

\section{How to cite this article:}

Navjot Kaur Dhillon, Pritpal Singh and Harinder Singh. 2020. Soil Organic Carbon, Phosphorus and Potassium in Soils under Poplar Based Agro-Forestry in Punjab. Int.J.Curr.Microbiol.App.Sci. 9(07): 1117-1124. doi: https://doi.org/10.20546/ijcmas.2020.907.131 